\title{
The Human Perception of Land Degradation in a Section of Niger Delta, Nigeria
}

\author{
Idowu Innocent Abbas ${ }^{1, *}$, Mayowa Johnson Fasona ${ }^{2}$ \\ ${ }^{1}$ Department of Geography, Ahmadu Bello University, Zaria, Nigeria \\ ${ }^{2}$ Department of Geography, University of Lagos, Nigeria
}

\begin{abstract}
This study looked at the perception of the people of the Niger Delta on the issue of land use-land cover changes and degradation that has been reported by several scholars to be wide spread in the study area as a result of anthropogenic factors and climate change. As a result of this, the study therefore used questionnaire and personal observation to investigate what the people thought about the land use-land cover changes, degradation, its causes, implications and how they are coping with it. It was found out that degradation such as erosion, flooding, saline water intrusion, devegetation, toxicity, subsidence, badlands, oil spillage and oil pollution were prevalent in the area. It was also discovered that the people were highly vulnerable as a result of poor coping strategies to the degradation and little or no assistance from the concerned authorities and multi nationals.
\end{abstract}

Keywo rds Perception, Degradation, Land use-Land Cover, Implications

\section{Introduction}

The increasing concern for the management of natural resources has been necessitated by the increasing demand for wealth and demographic pressures resulting in serious environmental stress and ecological instability. In the last 300 years, the impacts of land use-land cover changes (LULCC) have assumed dimension of significant proportions[1]. These impacts and changes have been found to be more profound in the developing countries, due to the high population growth rate and the subsequent resource over-exploitation.

As a result of poverty, people are forced to overexploit resources such as fisheries, forests and water in other to survive. The impacts of these environmental problems are serious both in the short and in the long term. In the short term food security, human vulnerability to hazards, health and safety are adversely affected; in the longer term the viability of the earth as a whole is being threatened[1].

The environment is so valuable and the inhabitants so precious that the future needs not be left to chance hence the need for regular auditing.

LULCC is driven by set of proximate and underlying factor elements central to environmental processes, change and management through their influence on biodiversity, heat and mo isture budgets, trace gas emissions, carbon cycling, livelihoods and a wide range of socio-economic

* Corresponding author:

innoabbas@yahoo.com (Idowu Innocent Abbas)

Published online at http://journal.sapub.org/ms

Copyright (C 2012 Scientific \& Academic Publishing. All Rights Reserved and ecological processes [2].

The proximate causes of land use- land cover changes (LULCC) explain how and why local land cover and ecosystem processes are modified directly by anthropogenic factors, while underlying causes explain the broader context and fundamental forces underpinning these local actions. In general, proximate causes operate at the local level (individual farms, households, or communities) and underlying causes originate from regional (districts, provinces, or country) or even global levels, though complex interp lays between these levels of organization are common.

Studying land use dynamics is essential for the understanding of various ecological and developmental consequences of LULCC over a space of time. This makes land use mapping and change detection relevant inputs into decision-making for implementing appropriate policy responses[2].

LULCC detection allows for the identification of major processes of change and, by inference, the characterization of land use dynamics. The reason for such consequence is as a result of over-dependence on primary resources with direct effect on biodiversity; land use and land cover dynamics, terrestrial ecosystem and climate (atmospheric composition, vegetation, temperature changes and occurrence of extreme climatic events). With rapid urbanization and a finite land area, the available land per individual is shrinking on a daily basis. This calls for an urgent need for proper geo- management of land that is dependent upon the availability of a detailed, accurate and up-to-date data.

LULCC is central to environmental processes, 
environmental change and environmental management through its influence on biodiversity, water budget, trace gas emissions, carbon cycling, livelihoods[3], and on a wide range of socio-economic and ecological processes [4] which on the aggregate affect global environ mental change and the biosphere. LULCC also plays important role in detecting emerging spatial patterns and the direction of land degradation, land fragmentation, decline of agricultural productivity, rural poverty and depopulation and environmentally-induced migration of people[3].

Land degradation is an integral part of environmental change process on land which leads to loss of valuable land resources. It also indicates a reduction in the resource potential of a land through the actions of those processes that may force the conditions of the land to become unpleasant and less useful to man. Such processes include water erosion, wind erosion, flood hazard, drought and desertification, devegetation, salinization, alkalization, loss of fertility, long term reduction in diversity of natural vegetation, reservoir sedimentation, toxicity hazards, mo isture stress, pollution, saline intrusion, subsidence, and permanent inundation of land among others[5]. These processes cause degradation of ecosystems services, reduction in the stability and resilience of the ecosystems, reduction in biological productivity potentials and ability of the land to withstand further disturbances, and impairment of ability to support human population and biodiversity. Land degradation resulting from unsustainable land use practices increases the disaster susceptibility of an area, and by implication the risk of the people living in such vulnerable areas [6].

Several scholars have established the fact that land use-land cover changes and degradation are widespread in the study area. Such scholars include[7; 8; 9; 10;11; 12; 13; $14 ; 15 ; 16 ;$ and 17]. As a result, the researcher decided to investigate the perception of the inhabitants of the Niger Delta to this serious is sue of land use-land cover changes and degradation using questionnaire and field observation. This will in turn help planners in solving the problem in such a way that the inhabitants will be carried along.

\subsection{The Study Area}

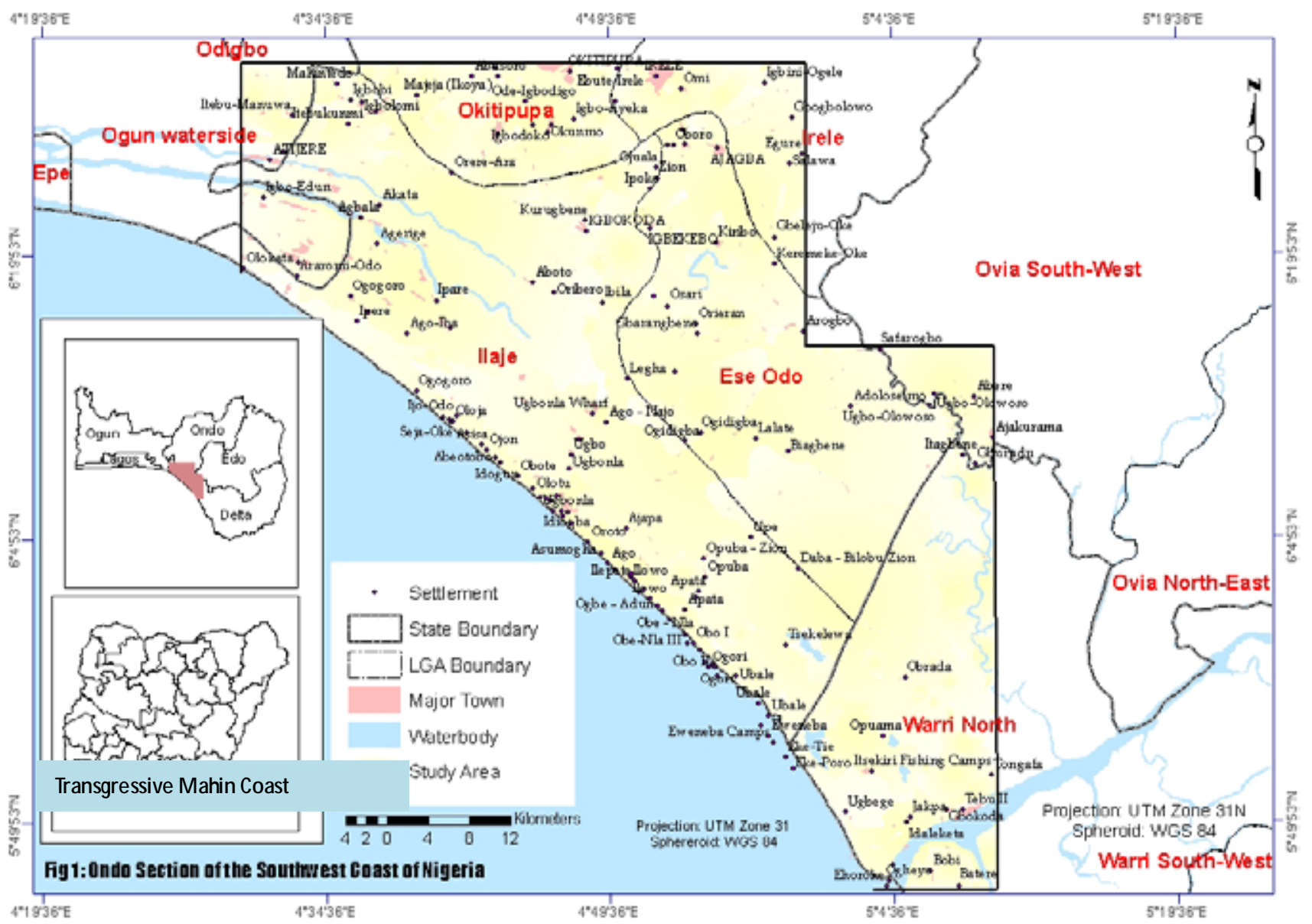

Figure 1. Transgressive Mahin Coast 
The study area is the Transgressive Mahin coastal area of the Niger Delta, Nigeria (figure 1). It lies approximately between latitudes $5^{0} 45^{1}$ and $6^{\circ} 30^{1}$ north of the Equator, and longitudes $4^{0} 30^{1}$ and $5^{0} 07^{1}$ East of the Greenwich. It covers an area of about $3,301 \mathrm{~km}^{2}$, with a mud coastline distance of $88 \mathrm{~km}$ and an inland distance of $50 \mathrm{~km}$ and $19 \mathrm{~km}$ respectively at its farthest and closest stretches from the Atlantic coastline. The area which extends to the lower parts of the Nigerian tar sand (bitumen) zone covers principally communities in Ilaje and Ese-Odo local government areas (LGAs) of Ondo state. It also extends to small parts of Ikale (Okitipupa) and Irele LGAs in Ondo state, Ogun waterside LGA in Ogun state, Warri North LGA in Delta state and Ovia Southwest LGA in Edo state.

The transgressiveMahin coastal area is bounded in the East by River Benin in Edo state, in the West by Ogun state coastline and in the North by Okitipupa and Irele local government areas. This area is parallel to Nigeria's South-West coastline, which is characterized by extensive lagoons and river- delta system. It is part of the 853 kilo metre length of the Nigerian coastline.

\section{Materials and Method}

Data on the perspective of the inhabitants of the Mahin coastal area on the implications of LULCC (land degradation and vulnerability) was sourced through the use of questionnaire. The questionnaire contains fifteen (15) open and close ended questions that asked about thesocio-economic characteristics of the population, the impacts of LULCC (hazards) on livelihood; and the peoples' vulnerability and coping strategies to these hazards. However, only the relevant questions to the study were analyzed. One thousand five hundred and sixty (1560) questionnaires were administered to the inhabitants of the area. Firstly, Stratified sampling technique was used to divide the study area into three strata. The first stratum (Stratum A) involved settlements within 0 to $15 \mathrm{~km}$ from the coast that is densely populated with high rate of LULCC. The second stratum (Stratum B) consists of settlements within 15 to $30 \mathrm{~km}$ from the coast that is sparsely populated due to the forest reserves and also of less LULCC. The third and the last stratum (Stratum C) contained settlements within 30 to $50 \mathrm{~km}$ from the coast because the population is equally high due to availability of land for farming activities and also of high LULCC. 725 questionnaires were given to people in stratum A and 700 returned, 315 questionnaires were administered to people in stratum B with 300 returned while 520 questionnaires were administered to people in stratum C and 500 returned. In all, a total of one thousand five hundred (1500) questionnaires constituting $0.003 \%$ of the population of the area were returned and analyzed.

The settlements selected from each stratum were selected by purposive sampling technique while the respondents were selected by accidental sampling technique. The justification for the use of $0.003 \%$ of the population and the use of the different sampling techniques was based on the nature of the terrain (creeks and lagoons); dispersed settlement pattern; inaccessibility of a large part of the study area by road and most importantly availability and the need to capture as much data as possible. The collected questionnaires were analyzed using descriptive statistics.

\section{Results and Discussion}

The perception of respondents to the questionnaire administered to them and the observation of the researcher in the field is as presented. Descriptive analysis is the basis for the questionnaire analysis.

Table 1. Income Distribution

\begin{tabular}{|c|c|c|}
\hline Income $(\mathrm{N})$ & Absolute No & Frequency \% \\
\hline$<5,000$ & 110 & 7.3 \\
\hline $5000-10000$ & 145 & 9.8 \\
\hline $11,000-15000$ & 506 & 33.7 \\
\hline $16000-20000$ & 425 & 28.3 \\
\hline$>20000$ & 314 & 20.9 \\
\hline Total & 1500 & 100 \\
\hline
\end{tabular}

Table 1 reveals that people with monthly income of $<\$ 5$, 000 were $7.3 \%$, monthly income of N5,000 - N10, 000 were $9.8 \%$, monthly income of N11, $000-\mathrm{N} 15,000$ were $33.7 \%$, monthly income of $\mathrm{N} 16,000-\mathrm{N} 20,000$ were $28.3 \%$ and monthly income of more than N20, 000 were $20.9 \%$. The implication of this statistic is that the poverty level was high in the study area with $79.1 \%$ of the population living below N20, 000 (less than 150 dollars per month).

Table 2. Occupation

\begin{tabular}{|c|c|c|c|c|}
\hline Occupation & $\begin{array}{c}\text { Major } \\
\text { No }\end{array}$ & Frequency \% & $\begin{array}{c}\text { Minor } \\
\text { No }\end{array}$ & Frequency \% \\
\hline Farming & 388 & 25.9 & 489 & 32.6 \\
\hline Fishing & 421 & 28.1 & 359 & 23.9 \\
\hline $\begin{array}{c}\text { Wine } \\
\text { Tapping }\end{array}$ & 124 & 8.3 & 88 & 5.9 \\
\hline $\begin{array}{c}\text { Civil } \\
\text { Servant }\end{array}$ & 300 & 21 & - & - \\
\hline $\begin{array}{c}\text { Trading / } \\
\text { Business }\end{array}$ & 212 & 14.1 & 524 & 34.9 \\
\hline $\begin{array}{c}\text { Others } \\
\text { (Artisan) }\end{array}$ & 55 & 3.6 & 40 & 2.7 \\
\hline Total & 1500 & 100 & 1500 & 100 \\
\hline
\end{tabular}

The occupations of the people of the study area were farming, fishing, wine tapping, trading/business, civil service and artisan. From table 2, it can be observed that the major occupations were fishing (28.17), civil service (20.0\%), trading / business enterprise (14.1\%), wine tapping (8.3\%) and others (artisan) 3.7\%. The minor occupations in the order of engagement were trading / business enterprise (34.9\%), farming (32.6\%), fishing $23.9 \%)$ wine tapping (5.9\%) and others (artisan) 2.7\%). 
Nobody was engaged in civil service job as a minor occupation. Putting all of those (major and minor occupations) together, it shows clearly that the dominant occupations were farming (29.2\%) fishing (26\%) and trading / business enterprise (24.5\%). The others were civil service job (10\%), wine tapping (7.1\%) and others (artisan) $3.2 \%$.

Table 3. Educational Status

\begin{tabular}{|c|c|c|}
\hline Education & Absolute No & Frequency $\%$ \\
\hline No formal Education & 500 & 33.3 \\
\hline Primary & 217 & 14.5 \\
\hline Secondary & 234 & 15.6 \\
\hline Tertiary & 423 & 28.2 \\
\hline Others & 126 & 8.4 \\
\hline Total & 1500 & 100 \\
\hline
\end{tabular}

Table 3 shows that about $60 \%$ of the respondents in the study area went to school with the level of educational attainment being primary education (14.5\%), secondary education (15.6\%), others (8.4\%) and tertiary education being $28.2 \%$. Those who did not go to any school at all were $33.3 \%$.

Table 4. Duration in study area

\begin{tabular}{|c|c|c|}
\hline Duration (years) & Absolute No & Frequency \% \\
\hline$<10$ & 383 & 25.5 \\
\hline $10-20$ & 664 & 44.3 \\
\hline$>20$ & 453 & 30.2 \\
\hline Total & 1500 & 100 \\
\hline
\end{tabular}

Table 4reveals that majority of the people (75.57\%) in the study area had stayed there for more than 10 years. This shows that majority of the respondents had the needed information about the area which the researcher needed. Only (25.5\%) of the respondents had stayed in the study area for less than 10 years.

From table 5, 28.7\% of the respondents reported that they were staying in the area because they were indigenes of the area, $36.4 \%$ responded that they came there to work, $30.9 \%$ said they came there as a result of trading / business enterprise while $4 \%$ said they were there for other reasons.

Table 5. Reason for Staying in study area

\begin{tabular}{|c|c|c|}
\hline Reason & Absolute No & Frequency \% \\
\hline Indigene & 430 & 28.7 \\
\hline Work & 546 & 36.4 \\
\hline Trading / Business & 464 & 30.9 \\
\hline Others & 60 & 4.0 \\
\hline Total & 1500 & 100 \\
\hline
\end{tabular}

Table 6. Ever experienced any of these degradation hazards

\begin{tabular}{|c|c|c|}
\hline Experienced & Absolute No & Frequency \% \\
\hline Erosion & 650 & 43.3 \\
\hline Flood & 865 & 57.7 \\
\hline Salt water Intrusion & 375 & 25 \\
\hline Devegetation & 924 & 61.6 \\
\hline $\begin{array}{c}\text { Oil spill / Oil } \\
\text { pollution }\end{array}$ & 688 & 45.9 \\
\hline $\begin{array}{c}\text { Sand excavation as } \\
\text { a bad land }\end{array}$ & 365 & 24.3 \\
\hline $\begin{array}{c}\text { Canalization } \\
\text { dredge spoil) }\end{array}$ & 500 & 33.3 \\
\hline Toxicity hazards & 320 & 21.3 \\
\hline $\begin{array}{c}\text { Subsidence (land } \\
\text { sinking) }\end{array}$ & 264 & 17.6 \\
\hline
\end{tabular}

Based on the information contained in table 6, it can be observed that a respondent chose more than one hazard making the total to be more than 1500 . $43.3 \%$ of the respondents had experienced erosion, $57.7 \%$ had experience d flood, $25 \%$ had experienced salt water intrusion, $61.6 \%$ had experienced devegetation. $45.9 \%$ had experienced oil spill / o il pollution, 24.3\% hadexperienced sand excavation, 33.3\% had experienced canalization as a result of pipeline routing, $21.3 \%$ had experienced toxicity hazard (disposal of chemicals) while $17.6 \%$ had experienced subsidence (sinking of land). This result shows that they had experienced all the land degradation types as defined by[5].

Table 7. Frequency of hazard experienced

\begin{tabular}{|c|c|c|c|c|c|c|c|c|c|c|}
\hline & \multicolumn{2}{|c|}{ Occasionally } & \multicolumn{2}{c|}{ Frequent Interval } & \multicolumn{2}{c|}{ Seasonally } & \multicolumn{2}{c|}{ Regularly } & \multicolumn{2}{c|}{ Total } \\
\hline & No & Freq $\%$ & No & Freq $\%$ & No & Freq $\%$ & No & Freq \% & No & $\begin{array}{c}\text { Freq } \\
\%\end{array}$ \\
\hline Erosion & - & - & - & - & 166 & 11.1 & - & & 166 & 11.1 \\
\hline Flood & - & - & - & - & 173 & 11.5 & - & & 173 & 11.5 \\
\hline $\begin{array}{c}\text { Salt water } \\
\text { intrusion }\end{array}$ & - & - & - & - & 184 & 12.3 & 72 & 4.8 & 256 & 17.1 \\
\hline Devegetation & - & - & - & - & - & - & 200 & 13.3 & 200 & 13.3 \\
\hline $\begin{array}{c}\text { Oil spill/ Oil } \\
\text { pollution }\end{array}$ & 30 & 2.0 & - & - & - & - & 269 & 17.9 & 299 & 19.9 \\
\hline $\begin{array}{c}\text { Sand } \\
\text { excavation }\end{array}$ & 19 & 1.3 & - & - & - & - & - & - & 19 & 1.3 \\
\hline $\begin{array}{c}\text { Toxicity } \\
\text { hazard }\end{array}$ & 15 & 1.0 & - & - & - & - & - & - & 15 & 1.0 \\
\hline Subsidence & 23 & 1.5 & - & - & 339 & 22.6 & - & - & 362 & 24.1 \\
\hline Canalization & 10 & 0.7 & - & - & - & - & - & - & 10 & 0.7 \\
\hline Total & 97 & 6.5 & - & - & 339 & 57.5 & 541 & 36.1 & 1500 & 100 \\
\hline
\end{tabular}


Table 8. Degree of Hazard Impact on Resources (Vulnerability)

\begin{tabular}{|c|c|c|c|c|c|c|c|c|}
\hline Resource & \multicolumn{2}{|c|}{ Severe Impact } & \multicolumn{2}{c|}{$\begin{array}{c}\text { Less Severe } \\
\text { Impact }\end{array}$} & \multicolumn{2}{|c|}{ Moderate Impact } & Total Abs. No & $\begin{array}{c}\text { Total } \\
\text { Freq. }\end{array}$ \\
\hline & No & Freq. \% & No & Freq. \% & No & Freq. \% & No & $\begin{array}{c}\text { Freq } \\
\%\end{array}$ \\
\hline $\begin{array}{c}\text { Drinking and Domestic } \\
\text { Water Sources }\end{array}$ & 542 & 36.1 & 696 & 46.4 & 262 & 17.5 & 1500 & 100 \\
\hline Fishing & 747 & 49.7 & 348 & 23.3 & 405 & 27 & 1500 & 100 \\
\hline Farmland/farming & 246 & 16.3 & 879 & 58.6 & 375 & 25.1 & 1500 & 100 \\
\hline Forest resources & 579 & 38.6 & 246 & 16.4 & 675 & 45 & 1500 & 100 \\
\hline Economic Activities & 976 & 65.1 & 478 & 31.9 & 46 & 3.1 & 1500 & 100 \\
\hline
\end{tabular}

Table 9. Coping strat egies to hazards

\begin{tabular}{|c|c|c|c|c|c|c|c|c|c|c|c|c|}
\hline \multirow[t]{2}{*}{ Hazard event } & \multicolumn{2}{|c|}{$\begin{array}{l}\text { Nothing(Leave } \\
\text { with it) }\end{array}$} & \multicolumn{2}{|c|}{$\begin{array}{c}\text { Tried to stop } \\
\text { it }\end{array}$} & \multicolumn{2}{|c|}{$\begin{array}{l}\text { Abandoned the } \\
\text { place and } \\
\text { moved }\end{array}$} & \multicolumn{2}{|c|}{$\begin{array}{l}\text { Complained } \\
\text { to } \\
\text { Government }\end{array}$} & \multicolumn{2}{|c|}{$\begin{array}{l}\text { Complained to } \\
\text { Oil companies }\end{array}$} & \multirow{2}{*}{$\begin{array}{c}\begin{array}{c}\text { Total } \\
\text { No }\end{array} \\
\text { No }\end{array}$} & \multirow{2}{*}{$\begin{array}{c}\text { Total } \\
\text { Freq. } \\
(\%)\end{array}$} \\
\hline & No & Freq. $\%$ & No & $\begin{array}{c}\text { Freq. } \\
\%\end{array}$ & No & $\begin{array}{l}\text { Freq. } \\
\%\end{array}$ & No & $\begin{array}{l}\text { Fre } \\
\text { q. } \%\end{array}$ & No & $\begin{array}{l}\text { Freq. } \\
\%\end{array}$ & & \\
\hline Erosion & 27 & 1.8 & 68 & 4.5 & 26 & 1.7 & 44 & 2.9 & - & - & 165 & 11 \\
\hline Flood & 203 & 13.5 & 65 & 4.3 & 69 & 4.6 & 30 & 2 & - & - & 367 & 24.5 \\
\hline $\begin{array}{l}\text { Salt Water } \\
\text { Intrusion }\end{array}$ & 87 & 5.8 & - & - & 150 & 10 & 36 & 2.4 & - & - & 273 & 18.2 \\
\hline Devegetation & 206 & 13.7 & 32 & 2.1 & 45 & 3 & - & - & - & - & 283 & 18.9 \\
\hline $\begin{array}{c}\text { Oil Spill / } \\
\text { Oil Pollut ion } \\
\end{array}$ & 36 & 2.4 & - & - & 24 & 1.6 & 15 & 1 & 4 & 0.3 & 79 & 5.3 \\
\hline $\begin{array}{c}\text { Sand } \\
\text { Excavation }\end{array}$ & 84 & 5.6 & - & - & - & - & - & - & - & - & 84 & 5.6 \\
\hline Canalization & 87 & 5.8 & - & - & 21 & 1.4 & - & - & - & - & 108 & 7.2 \\
\hline $\begin{array}{l}\text { Toxicity } \\
\text { Hazards }\end{array}$ & 33 & 2.2 & - & - & 15 & 1 & - & - & 9 & 0.6 & 57 & 3.8 \\
\hline Subsidence & 36 & 2.4 & - & - & 30 & 2 & 18 & 1.2 & - & - & 84 & 5.6 \\
\hline Total & 799 & 53.2 & 165 & 10.9 & 380 & 25.3 & 143 & 9.1 & 13 & 0.9 & 1500 & 100 \\
\hline
\end{tabular}

From table 7, it can be observed that erosion (11.1\%) and flood (11.5\%) were experienced seasonally especially during the rainy season. Salt water intrusion (17.1\%) and devegetation (13.3\%) were experienced regularly in the study area while oil spill / oil pollution (19.9\%), canalization for pipeline $(0.7 \%)$, sand excavation for oil drilling $(1.3 \%)$, toxicity hazards (disposal of chemicals) $1.0 \%$ and subsidence (sinking of land) $24.1 \%$ occurred occasionally.

From table 8 , about $36.1 \%$ of the respondents claimed that their drinking water and water for domestic sources were severely affected by the various hazards. About $46.4 \%$ claimed that the impact was less severe while $17.5 \%$ claimed it was a moderate impact.

For fishing ponds, about $49.7 \%$ said they were severely affected, $23.3 \%$ said they were less severely affected while $27.0 \%$ claimed they were moderately affected. For farmlands/farming, $16.3 \%$ of the respondents said they were severely affected, $58.6 \%$ said they were less severely affected while $25 \%$ said they were moderately affected. Moreover, about $38.6 \%$ of the respondents believed forest resources were severely affected; $16.7 \%$ were of the opinion that it was less severely affected while $45 \%$ said it was moderately affected. Concerning economic activities / livelihood sources, $65.1 \%$ of the respondents were severely affected, 31.9\% said they were less severely affected while $31 \%$ claimed they were moderately affected. This shows that

the land degradation hazards were impacting them greatly especially their means of livelihoods

\subsection{Coping Strategies to Hazards}

The response to coping strategies to the hazards by the people of the study area is as shown in table 9 .

Table 9 reveals that for erosion, $1.8 \%$ of the respondents reported that they did nothing since they were not empowered, $4.5 \%$ said they tried to stop it in their own way, $1.7 \%$ said they abandoned the place and moved to new land while $2.9 \%$ complained to the government. In the case of flood, $13.5 \%$ did nothing, $4.3 \%$ tried to stop it, $4.6 \%$ abandoned the place and moved to new area and $2 \%$ complained to the government. For saltwater intrusion, $5.8 \%$ did nothing while $10 \%$ abandoned the place and moved to new lands while $10 \%$ complained to the government.

When devegetation happened, $13.7 \%$ did nothing, $2.1 \%$ tried to stop while $3 \%$, abandoned the place and moved to new lands. For oil spill / oil pollution, $2.4 \%$ did nothing, $1.6 \%$ abandoned the place and moved to new lands while $1 \%$ complained to the government. In respect of sand 
excavation for oil drilling, 5.6\% did nothing. In the case of canalization, $5.8 \%$ did nothing while $1.4 \%$ said they reported the incidence to the government. For toxicity hazards, $2.2 \%$ did nothing, $2 \%$ abandoned the place for new lands while $1.2 \%$ reported to the government. During subsidence, $4.4 \%$ did nothing. From the above it is very obvious that the adaptive and coping capacity of the inhabitants of the study area to the various hazards was very low.

In summary, from the questionnaire analysis, it is obvious that the inhabitants were exposed to several land degradation

hazards as a result of land use land cover changes necessitat ed mainly by the activities of the oil exploration/exploitatio $\mathrm{n}$ in the study area, developmental projects and climate change effects. It is also worth noting that as a result of the numerous types of land degradation the inhabitants faced grave challenges of threat to their means of livelihood especially with very low adaptive/coping capacity.

\subsection{External Assistance}

The source of assistance to the people of the study area as contained in their responses is as shown in table 10.

Table 10. Source of Assistance

\begin{tabular}{|c|c|c|c|c|}
\hline Source & \multicolumn{4}{|c|}{ Assistance } \\
\hline & Yes & Freq. \% & No & Freq. \% \\
\hline Government & 50 & 3.3 & 1450 & 96.7 \\
\hline OSOP ADEC & 1368 & 91.27 & 132 & 8.8 \\
\hline NDDC & 806 & 53.7 & 694 & 46.3 \\
\hline Oil Company & 735 & 49 & 765 & 51 \\
\hline NGO & 37 & 2.5 & 1463 & 97.5 \\
\hline $\begin{array}{c}\text { Community } \\
\text { Based } \\
\text { Organization }\end{array}$ & 10 & 0.7 & 1490 & 99.3 \\
\hline Individuals & 63 & 4.2 & 1437 & 95.8 \\
\hline
\end{tabular}

Table 10 reveals that, $3.3 \%$ received assistance from the government, $91.27 \%$ received assistance from OSOPADEC, $53.7 \%$ had received assistance from NDDC, 49\% received assistance from oil companies, $2.4 \%$ from NGOs, $0.7 \%$ from community based organizations and $42 \%$ from individuals, especially politicians. This implies that the sources of assistance were mainly from OndoState Oil Producing Area Development Commission and Niger Delta Develop ment Commission.

Source:[18]

In summary, from the questionnaire analysis, it is obvious that the inhabitants were exposed to several land degradation hazards as a result of land use-land cover changes necessitated mainly by the activities of the exploitation and exploration and non-sustainable developmental projects by the various government agencies in the study area coupled with climate change effects as shown in figure 2.The flooding resulted from multiple of causes such as erosion (note the shoreline on the top side of figure 2), low ly ing topography and sea level rise[3]. It is also worth noting that as a result of the numerous types of land degradation the inhabitants were vulnerable to various disasters due to loss of settlements and livelihoods.

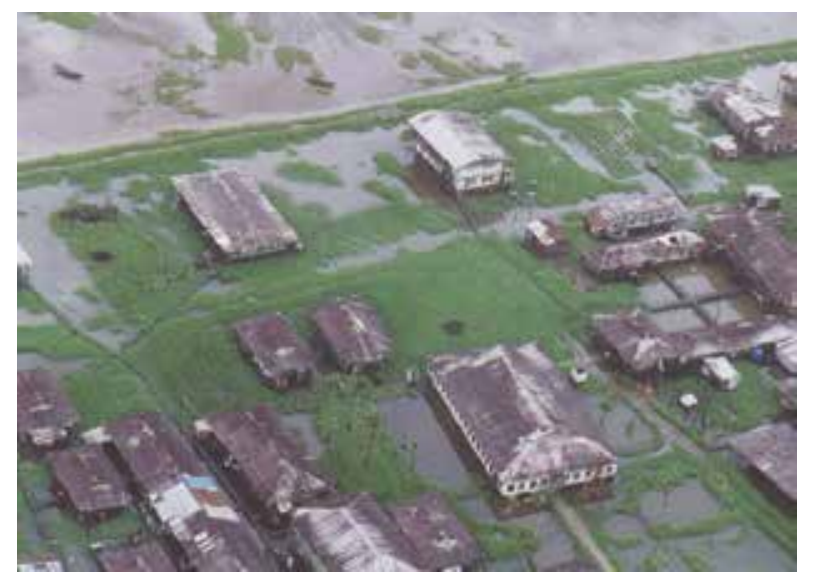

Figure 2. Flooding of Aiyetoro community along the Transgressive Mahincoast

\section{Conclusions}

The problem of LULCC leading to land degradation and human vulnerability were as a result of anthropogenic factors especially oil exploration and exploitation activities in the study area. It is also observed that the various developmental projects by the Niger Delta development Commission and other agencies such as Ondo State Oil Producing Area development Commission had also contributed to the degradation witnessed in the study area as a result of poor planning and non-completion of projects. It is also note stating that the effects of climate change were visible in the study area. The implications of the degradation as expressed by the people were really biting hard and there is an urgent need by the government and all concerned to do something to stem the conditions of the people before a serious disaster is witnessed in the study area.

\section{REFERENCES}

[1] Briassoullis, H,Analysis of Land Use Change: Perspectives, Theoretical and Modeling Approaches, Earths- Can Publication Ltd, London www.idosi.org/aejsr/1 (1)06/7, 1999

[2] Fasona, M. J and Omojola A.S, Climate Change, Human Security AndCommunal Clashes in Nigeria,Proceedings of the InternationalWorkshop on Human Security and Climate Change, Holmen Fjord Hotel, Asker, near Oslo, 22-23 June 2005,www.cicero.uio.no/humsec/papers/Fasona\&Omojola.p df

[3] Verburg, P.H; Chen, Y; Soepboer, W and Veldkamp, T.A, GIS-based modeling of human- environment interactions for natural resource management Applications in Asia, Proceedings of the 4th International Conference on 
Integrating GIS and Environmental Modeling: Problems, Prospect and Research Needs, Banff, Alberta, Canada, 2000

[4] Desanker, P.V; Frost, P.G.I; Justice, C.O and Scholes, R.J,TheMiombo Network: Frameworks for a terrestrial transect study of land use and land Cover change in the Miombo ecosystems of Central Africa. IGBP Report41, pp109. www.geo.ucl.ac.be/LUCC/data/miombo, 1997

[5] Abdukadir, A, Remote Sensing and Land Degradation. Nigerian Journal of Remote Sensing, Vol. 1(1), pp 65-72, 1993

[6] Verstappen, H.T, Environmental Hazards and the Use of Satellite Remote Sensing for Sustainable Development, Adeniyi, P.O (ed): Geo-informalion Technology Applications for Resource \& Environmental Management in Africa, AARSE, 57-64p, 1999

[7] Fasona, MJ, Coastal Flooding Risk and Community Adaptive Strategies in the Western Niger Delta, Journal of Environment and Behavior, Vol 1 pp56-62, 2003

[8] Fasona, M.J, Land Degradation and Environmental Change in Ondo State, South-West, Nigeria, An (unpl) $\mathrm{PhD}$ thesis, University of Lagos, 2007

[9] Abbas, I.I, An assessment of land use-land cover changes and their Implications on land resources and livelihood in the Mahin area of the Niger Delta region Nigeria, An (unpl) PhD thesis, Ahmadu Bello University, Zaria, 2011

[10] UNDP, Niger Delta Human Development Report, pp 229, 2006

[11] Spiff, A.I and Horsfall, M. Jnr, Trace Metal Concentration in Inter-Tidal flat Sediments of the Upper New Calabar River in the Niger Delta area of Nigeria, Sciential Africana, 3, 19-28, 2004
[12] Otukunefor, T.V and Biukwu, C.O, Impact of Refinery Influent on Physico-Chemical Properties of a water body on The Niger-Delta, Journal of Applied Ecology and Environmental Research 3(1), pp61-72, 2005

[13] Orubu, C.O, Petroleum-Induced Environmental Diseconomies and Sustainable Development, In: The Petroleum Industry, the economy and the Niger-Delta Environment, (eds), Orubu, C.O; O gisi, D.O and Okoh, R.N, pp 17-31, 2002a

[14] Omo- Irabor, O.O and Oduyemi, K, A hybrid Image Classification Approach for the systematic analysis of landcover (LC) changes in the Niger Delta region, Department of Built and Natural Environment, School of Contemporary sciences, University of Abertay, Scotland, 2007

[15] Oluwole, A.F; Olaniyi, H.B; Akeredolu, F.A; Ogunsola, O. J and Obioh, I.B, Impact of the Petroleum Industry on Air Quality in Nigeria, Paper Presented at the 8th Biennial International seminar on the Petroleum Industry and the Environment, Portharcourt, pp 17-21, November, 1996

[16] Nwokedi, M,Environmental Sensitivity Index Mapping of Areas around the ForcadosRiver, AnM.Sc thesis (unpl), Department of Geography, University of Lagos, 1999

[17] Olobaniyi, S.B and Efe, S.I, Comparative Assessment of rainwater and ground water quality in an oil producing area of Nigeria: Environmental and Health Implications, Journal of Environmental Health and Research, (6)2: 111- 118, 2007

[18] Awosika, L.F., Osuntogun, N.C., Oyewo, E.O. and Awobamise, A, Development and Protection of the Coastal and Marine Environment in Sub sahara Africa: Report of the Nigerian Integrated Problem Analysis on Development and Protection of the Coastal and Marine Environment in Sub-Saharan Africa 15, 16 pp, 2001. 